\title{
RESEARCH
}

Open Access

\section{Prioritising health research in KwaZulu- Natal: has the research conducted met the research needs?}

\author{
G. Khumalo ${ }^{1 *}$, R. Desai ${ }^{1}$, X. Xaba ${ }^{1}$, M. Moshabela ${ }^{2}$, S. Essack ${ }^{3}$ and E. Lutge ${ }^{1,2}$
}

\begin{abstract}
Background: The KwaZulu-Natal (KZN) Health Act of 2009 mandates the Provincial Health Research and Ethics Committee to develop health research priorities for the province. During 2013, the KZN Department of Health embarked on a research prioritisation process for the province. Priority research questions were generated by an inclusive process, in which a variety of stakeholders in health research in the province were engaged. The aim of this study was to determine whether research conducted at public health facilities in KZN between 01 January 2014 and 31 March 2017 met the research priorities of the province developed through the provincial research prioritisation process of 2013.
\end{abstract}

Methods: This was a mixed methods study. Qualitative thematic analysis was used to categorise priority research questions generated in the priority-setting process and the titles of research projects conducted after that process into themes. Quantitative analysis was used to determine the correlation between themes of the priority questions, and those of the research projects conducted after the prioritisation exercise. Statistical Package for Social Science version 25 was used to analyse the data.

Results: In $72 \%$ of thematic areas, there were disproportionately more priority questions than there were research projects conducted. There is thus a large disjuncture between the priorities developed through the provincial research prioritisation process of 2013 and the research projects conducted after that process in terms of major research areas.

Conclusions: Ensuring that research conducted responds to priority questions raised is important because it ensures that research responds to locally important issues and to the concerns of local actors. Local health managers, communities and researchers should work together to ensure that the research conducted in their areas respond to the research priorities of those areas. Health Research Committees and local ethics committees can play important roles in facilitating the responsiveness to research priorities.

Keywords: research prioritisation, research priorities, prioritising research, priority research setting

\footnotetext{
* Correspondence: gugu.khumalo@kznhealth.gov.za

${ }^{1}$ KwaZulu-Natal Department of Health, Health Research \& Knowledge Management Unit, 330 Langalibalele Street, Pietermaritzburg, South Africa Full list of author information is available at the end of the article
} 


\section{Background}

Research is recognised as an important tool to improve health and healthcare in South Africa. It ranks as one of the priorities of the National Department of Health $(\mathrm{NDoH})$ in its ten-point plan [1] and is one of the key interventions of the KwaZulu-Natal (KZN) Provincial Growth and Development Plan [2]. However, because resources for research are limited, it is crucial to ensure that research is relevant for its target population.

The National Health Research Committee is tasked through the National Health Act (61 of 2003) with developing a national strategy for health research, ensuring that "health research agendas and research resources focus on priority health problem" ([3], p. 73). The NDoH held a national health research prioritisation exercise in 2011. Previous exercises had been held in 1996 and 2006. However, the effects of these research prioritisation exercises have not, to our knowledge, been evaluated. Specifically, the extent to which research conducted after such prioritisation answers the priority research questions identified has not been investigated.

In KZN, the KZN Health Act (2009) requires that the Provincial Health Research and Ethics Committee sets research priorities for the province and, accordingly, a research prioritisation exercise was conducted in 2013 [4]. A total of four workshops were conducted across the province, with clinicians, researchers and academics from a variety of organisations as well as representatives from non-governmental, community- and faith-based organisations. A total of 1018 priority research questions were identified, communicated to the leaders of all academic and research organisations in $\mathrm{KZN}$, and posted on the KZN Department of Health (KZN-DoH) website to encourage the answering of these priority questions through research projects.

The main aim of the study was to determine the extent to which research conducted at public health facilities in KZN between 01 January 2014 and 31 March 2017 has met the research priorities of the province as developed in the research prioritisation process held in 2013. There were three objectives of the study. The first was to categorise the research questions developed during the prioritisation process of 2013 into thematic areas. The second was to categorise the research projects conducted between 01 January 2014 and 31 March 2017 into thematic areas, and the third was to investigate the level of concordance between the thematic areas of the priority research questions and those of the research projects conducted after the prioritisation process.

\section{Methods}

\section{Data collection}

The titles of research projects that had been conducted in the KZN public health facilities were obtained from the database of the Health Research and Knowledge Management Unit (HRKMU) of the $\mathrm{KZN}-\mathrm{DoH}$, which provides the provincial approval for all research conducted at provincial health facilities in the province. The priority research questions, as articulated through the research prioritisation process of 2013, were available from the KZN-DoH website.

\section{Data analysis}

The titles of research projects conducted, and the priority research questions, were organised by three teams of investigators into themes. Each team consisted of two investigators who were paired to code both questions and titles according to deductive themes and subthemes guided by the broad Burden of Disease [5] and the WHO framework [6], as seen in Table 1. Then, each pair swapped their coding so that the next pair would code the same questions and titles. Whenever there were disagreements on the coding, a meeting was held to find consensus on coding. After the consensus meeting, themes and subthemes were finalised.

Each title and research question was allocated two themes (a primary theme and a secondary theme) from either category. A grid structured according to these themes was developed (Appendix 1). Each title or question was coded first according to the primary theme and then according to the secondary theme. Thereafter, each coded title was placed into a specific cell in the grid for research titles, and each coded research question was allocated to a specific cell in the grid for research questions. This resulted in two grids - one for research titles, the other for research questions. The extent to which these two grids overlapped was then statistically assessed.

This statistical analysis was done in SPSS version 25. Each cell on each grid was allocated an SPSS

Table 1 Two sets of themes developed

\begin{tabular}{ll}
$\begin{array}{l}\text { Themes relating to burden } \\
\text { of disease }\end{array}$ & $\begin{array}{l}\text { Themes relating to the building blocks of } \\
\text { a health system }\end{array}$ \\
\hline $\begin{array}{l}\text { Maternal and child health } \\
\text { Teenage pregnancy }\end{array}$ & $\begin{array}{l}\text { Service delivery } \\
\text { Quality of care }\end{array}$ \\
$\begin{array}{l}\text { Sexual and reproductive } \\
\text { health }\end{array}$ & Health system \\
$\begin{array}{l}\text { Tuberculosis } \\
\text { HIV }\end{array}$ & Human resources management \\
$\begin{array}{l}\text { Adherence (to treatment) } \\
\text { Non-communicable diseases, } \\
\text { including injuries }\end{array}$ & $\begin{array}{l}\text { Traditional medicine } \\
\text { Mental health }\end{array}$ \\
Substance use & $\begin{array}{l}\text { Clinical management and leadership/ } \\
\text { governance }\end{array}$ \\
\hline
\end{tabular}


Table 2 Frequency showing research area needs that were met and unmet

\begin{tabular}{|c|c|c|c|}
\hline & Questions & Titles & Titles/Questions (\%) \\
\hline Adherence & 2.6 & 1.3 & 0.50 \\
\hline Clinical management & 4.4 & 18.4 & 4.18 \\
\hline Community health & 5.6 & 1 & 0.18 \\
\hline Epidemiology & 2.2 & 13.5 & 6.14 \\
\hline Evaluation/impact & 2.4 & 1.1 & 0.46 \\
\hline Geography & 1.8 & 0.4 & 0.22 \\
\hline Health economics & 2.1 & 0.5 & 0.24 \\
\hline Health policy & 1.2 & 1.2 & 1.00 \\
\hline Health promotion & 3 & 0.7 & 0.23 \\
\hline Health systems & 9.6 & 4.1 & 0.43 \\
\hline HIV/AIDS & 8.3 & 4.2 & 0.51 \\
\hline $\begin{array}{l}\text { Human resources } \\
\text { management }\end{array}$ & 10.1 & 10 & 0.99 \\
\hline $\begin{array}{l}\text { Infection prevention } \\
\text { and control }\end{array}$ & 0.5 & 0.8 & 1.6 \\
\hline $\begin{array}{l}\text { Infectious/ } \\
\text { communicable disease }\end{array}$ & 1.2 & 1.6 & 1.33 \\
\hline Information systems & 5.2 & 4.1 & 0.79 \\
\hline $\begin{array}{l}\text { Intersectoral } \\
\text { collaboration }\end{array}$ & 3.1 & 0.4 & 0.13 \\
\hline $\begin{array}{l}\text { Inter-sectoral } \\
\text { collaboration, traditional }\end{array}$ & 0.5 & 0 & 0.00 \\
\hline Malaria & 1.7 & 0.4 & 0.24 \\
\hline $\begin{array}{l}\text { Maternal and child } \\
\text { health }\end{array}$ & 8.2 & 5.8 & 0.71 \\
\hline Mental health & 1.4 & 2.2 & 1.57 \\
\hline $\begin{array}{l}\text { Non-communicable } \\
\text { diseases }\end{array}$ & 0.1 & 9.2 & 92.00 \\
\hline Nutrition & 0 & 0.6 & 0.00 \\
\hline $\begin{array}{l}\text { Occupational } \\
\text { health and safety }\end{array}$ & 1 & 1 & 1.00 \\
\hline Pregnancy-related healthcare & 2.2 & 1.1 & 0.50 \\
\hline Quality of care & 3.1 & 2.4 & 0.77 \\
\hline Service delivery & 3.4 & 2.5 & 0.74 \\
\hline Sexual and reproductive health & 1.4 & 1.5 & 1.07 \\
\hline $\begin{array}{l}\text { Socio-behavioural and } \\
\text { cultural factors }\end{array}$ & 7.5 & 5.1 & 0.68 \\
\hline Substance use & 0.1 & 0 & 0.00 \\
\hline Tuberculosis & 4.1 & 3.9 & 0.95 \\
\hline Teenage pregnancy & 0.7 & 0.5 & 0.71 \\
\hline Traditional medicine & 1.3 & 0.5 & 0.38 \\
\hline Total & 100 & 100 & $\begin{array}{l}23 / 32(72 \%) \text { higher } \\
\text { frequency of questions } \\
\text { than titles }\end{array}$ \\
\hline
\end{tabular}

${ }^{a}<1$ indicates a research area need not met 
code, which was a combination of the theme on the $x$ axis (primary theme) and the theme on the $y$ axis (secondary theme). For example, if the primary theme was 'HIV' and the secondary theme was 'Quality of Care', then the final SPSS code was 'HIV/Quality of Care'. The frequency of the matching SPSS codes between the questions and titles was used to determine the extent to which priority research questions were answered by research projects.

\section{Results}

A total of 1018 priority research questions and 1235 research titles were categorised into 32 primary and secondary themes. Table 2 shows the frequency of priority questions and project titles in each theme. Where the frequency is higher for the priority questions than that of the titles, this indicates that research needs were identified but not met. Where the frequency is higher for the project titles, this indicates that more research was conducted on a theme than was considered important during the prioritisation process. Where the frequencies are the same, this means that the research need identified through the prioritisation process was met by the research projects conducted. Overall, in 23 of the 32 themes developed, there was a higher frequency of research questions than titles, indicating that more questions were asked around this theme than research projects were conducted.

Figure 1 shows the frequency of primary themes for the research questions and research titles, where the percentage of each theme represents the relative number of times that theme occurred within the questions and titles, respectively. This figure illustrates the relative discrepancies between the primary themes of the priority research questions and the subsequent research projects.

As seen in Table 2 and Fig. 1, there was frequency discrepancy between conducted research and local research prioritisation questions. The themes that had no research conducted on them were Intersectoral collaboration, traditional, and Substance use. As seen in Table 3, $0.5 \%$ of the questions for Intersectoral collaboration, traditional, were on Geography and Health systems and HIV/AIDS and Traditional medicine were secondary themes. However, no research was conducted on Intersectoral collaboration during this study period. On Substance use, $0.1 \%$ of the questions were on the Community health as a secondary theme but no research was conducted on Substance use.

Other under researched themes were Geography, Health promotion and Malaria, where research conducted was almost 0.2 times less that the research needed by the Province.

The themes that were mostly researched were Noncommunicable diseases (NCDs) followed by Epidemiology and lastly Clinical management.

As seen in Table 4, on the NCD theme, the research prioritisation process questions had $0.1 \%$ of questions around the NCDs all of which were under the Community health secondary theme. However, research conducted on NCDs was $9.2 \%$, which is 92 more times than what the Province indicated. Research was conducted mostly around Epidemiology (4.4.\%) and Evaluation/impact (4.1\%) secondary themes.

For Epidemiology, six times more research (13.5/ 2.2) was conducted than what was indicated by the

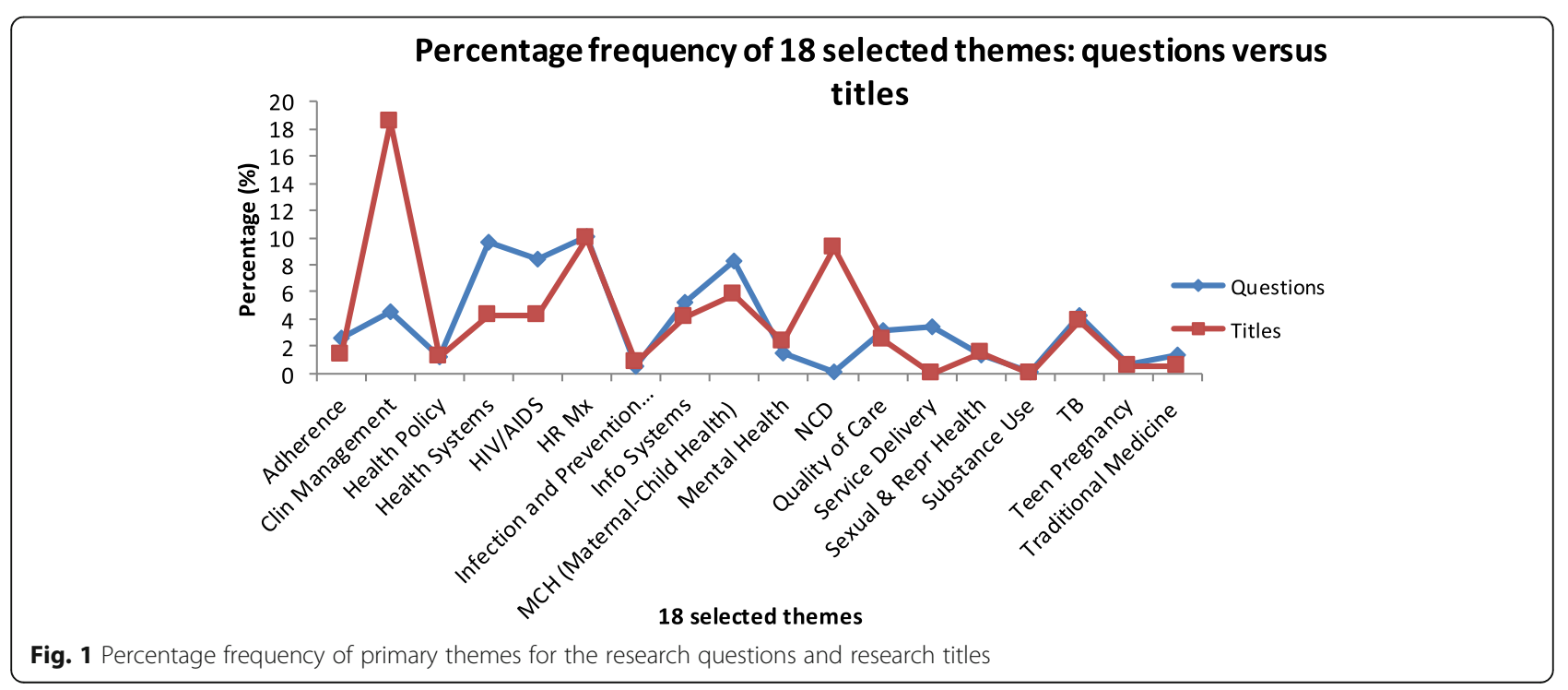


Table 3 Under researched health theme - Intersectoral collaboration, traditional

\begin{tabular}{lll}
\hline & \multicolumn{2}{l}{ Theme: Intersectoral collaboration, traditional } \\
\cline { 2 - 3 } & Questions & Titles \\
\hline Geography & 0.1 & 0 \\
Health systems & 0.2 & 0 \\
HIV/AIDS & 0.1 & 0 \\
Traditional medicine & 0.1 & 0 \\
Total & 0.5 & 0 \\
\hline
\end{tabular}

province (Table 5). Mostly the province indicated a need around Evaluation/impact (0.9\%) and Nutrition $(0.6 \%)$ secondary themes. However, no research was conducted around these secondary themes but instead research was conducted mostly around NCDs (5.3\%) and HIV/AIDS (3.6\%) as secondary themes.

For Clinical management, four times more research was conducted in the Province related to priority research questions $(18.4 \% / 4.4 \%)$ as seen in Table 6. For example, looking at the Evaluation/Impact secondary theme, $2 \%$ of priority questions were on this theme compared to $3.6 \%$ of research projects that were conducted around this theme.

Some themes occurred with a similar frequency for research questions and titles. For example, Sexual and reproductive health had $1.4 \%$ research questions versus $1.5 \%$ titles. However, differences occurred in the secondary themes as seen in Table 7 regarding the specific aspects of sexual and reproductive health that were identified as priority research questions and that were the focus of research projects. Here, no priority questions looked at the epidemiology of sexual and reproductive health, and yet this was the focus of $0.3 \%$ of research projects. Similarly, whilst $0.4 \%$ of priority questions focused on teenage pregnancy within the theme of sexual and reproductive health, no research projects investigated this issue.

Table 4 Over researched health theme: Non-communicable diseases

\begin{tabular}{lll}
\hline & \multicolumn{2}{l}{ Non-communicable diseases } \\
\cline { 2 - 3 } & Questions & Titles \\
\hline Adherence & 0 & 0.2 \\
Community health & 0.1 & 0.1 \\
Epidemiology & 0 & 4.4 \\
Evaluation/impact & 0 & 4.1 \\
Health systems & 0 & 0.2 \\
Human resources management & 0 & 0.4 \\
Total & $\mathbf{0 . 1}$ & $\mathbf{9 . 2}$ \\
\hline
\end{tabular}

Table 5 Over researched health theme: Epidemiology

\begin{tabular}{lll}
\hline & Epidemiology & \\
\cline { 2 - 3 } & Questions & Titles \\
\hline Clinical management & 0.3 & 0.3 \\
Community health & 0.1 & 0 \\
Evaluation/impact & 0.9 & 0 \\
Health promotion & 0 & 0.1 \\
HIV/AIDS & 0 & 3.6 \\
Human resources management & 0 & 0.1 \\
Intersectoral collaboration & 0.1 & 0 \\
Maternal and child health & 0 & 2.8 \\
Non-communicable diseases & 0 & 5.3 \\
Nutrition & 0.6 & 0 \\
Pregnancy-related healthcare & 0 & 1.1 \\
Socio-behavioural and cultural factors & 0.1 & 0 \\
Substance use & 0.1 & 0.2 \\
Teen pregnancy & 0 & 0.1 \\
Total & 2.2 & 13.5 \\
\hline
\end{tabular}

Such detailed identification of the mismatch between research questions and research titles can be seen for the remaining themes in Appendix 2.

\section{Discussion}

This study is, to our knowledge, the first to evaluate the implementation of a health research prioritisation exercise, in that it investigated the extent to which research projects focused on the issues raised in a research prioritisation exercise. Whilst a number of papers have considered the health research prioritisation process itself [7-12], none to our knowledge have looked at the effectiveness of such exercises. The evaluation of the implementation of research prioritisation exercises is important, because failure to conduct research on the priorities identified renders the prioritisation process useless and the resources spent on it wasted.

The study has shown that, following the identification of priority health research questions in $\mathrm{KZN}$, the research projects conducted responded to the questions asked to varying degrees. Whilst the frequency of some primary themes are very similar in the priority questions and the research titles, in others, there are important differences, indicating that either priority questions were raised but were not addressed in research projects or that, despite not being identified as priority areas, research projects were conducted around certain themes. Even where the frequency of primary themes was similar across questions and 
Table 6 Over researched health theme: Clinical management

\begin{tabular}{lll}
\hline Clinical management & & \\
\hline Evaluation/impact & 2 & Titles \\
Health systems & 0.7 & 3.6 \\
HIV/AIDS & 0.9 & 0.7 \\
Human resources management & 0 & 2.6 \\
Information systems & 0.1 & 0.6 \\
Maternal and child health & 0.3 & 0 \\
Mental health & 0.2 & 2.2 \\
Non-communicable diseases & 0.2 & 0 \\
Pregnancy-related healthcare & 0 & 6.2 \\
Sexual and reproductive health & 0 & 0.9 \\
Socio-behavioural and cultural factors & 0.1 & 0.2 \\
Tuberculosis & 0 & 0.1 \\
Teenage pregnancy & 0 & 1.3 \\
Total (percentage) & 4.4 & 0.1 \\
\hline
\end{tabular}

titles, the frequency of secondary themes often showed discrepancies.

There is a discrepancy between local research priority and actual research conducted where one is either more or less than the other. This can be seen, for example, in the NCD theme, where more research was conducted than the prioritisation questions, as well as in the Intersectoral collaboration, traditional, theme, where no research was conducted even though this theme was indicated as a local priority during the prioritisation process. This reflects the degree of attractiveness of certain health areas where some are more attractive than the others. When weighing this attractiveness, it seems that either both funders and researchers are naïve of the research priority areas of

Table 7 Comparison of secondary themes under the primary theme of Sexual and reproductive health

\begin{tabular}{lll}
\hline & $\begin{array}{l}\text { Questions } \\
\text { Sexual and reproductive health (\%) }\end{array}$ \\
\hline Community health & 0 & 0.1 \\
Epidemiology & 0 & 0.3 \\
Evaluation/impact & 0.7 & 0.4 \\
Health systems & 0.2 & 0 \\
Human resources management & 0.1 & 0.4 \\
Maternal and child health & 0 & 0.2 \\
Teenage pregnancy & 0.4 & 0 \\
Traditional medicine & 0 & 0.1 \\
Total (percentage) & $\mathbf{1 . 4}$ & $\mathbf{1 . 5}$ \\
\hline
\end{tabular}

the province or, if they are conscious about it, chose to ignore it. Prior to conducting research, researchers should self-reflect on what and how to prioritise research topics particularly in this era of "decolonizing" and "participatory/embedded" research [13]. Researchers play an important role in weighing the balance between global and local research interests, and finding ways of supporting locally relevant research drawn from local research prioritisation processes.

Ensuring that the research conducted responds to the priority questions raised is important because it ensures that research responds to locally important issues, and to the concerns of local actors. Both of these make it more likely that the results of research will be used in policy and practice. It is clear that researchers' response to the KZN Research prioritisation process of 2013 was variable. The KZN HRKMU did not have the resources to fund research on priority questions, nor did HRKMU consider refusing permission for any research that did not respond to a priority question. We regard the latter as restrictive, because we acknowledge that research is a creative process and an important part of academic freedom and 'scholarly debate' [14].

\section{Conclusion}

This assessment of the effectiveness of a research prioritisation process was one of the first studies of its kind. It shows that under one-third of the themes of priority questions developed in the KZN research prioritisation process were reflected in subsequent research projects. Thus, many areas of health and healthcare considered as priorities in the province remain under-researched. The province relies on evidence found through research to inform and improve the health system. It is hoped that subsequent research priorities will be met by research projects in the future, whilst maintaining the balance between freedom of academic enquiry and rooting research in agreed areas of priority.

\section{Recommendations}

As the burden of disease in South Africa shifts and health issues take different levels of priority, research prioritisation processes can play an important role in directing local health research. The communication of research priorities resulting from these processes should be enhanced, and local funding made available, to encourage studies that focus on priority research questions. Local health managers, communities and researchers should work together to ensure that the research conducted in their areas responds to the research priorities of those areas. This will require the strengthening of relationships at all levels. Provincial Health Research Committees and local ethics committees can play important roles in facilitating this. 


\section{Appendix 1}

Table 8 Grid to show distribution of research titles/questions according to thematic area

\begin{tabular}{|c|c|c|c|c|c|c|c|c|}
\hline $\begin{array}{l}\text { Themes } \\
\text { Themes }\end{array}$ & Adherence & $\begin{array}{l}\text { Clinical } \\
\text { management }\end{array}$ & $\begin{array}{l}\text { Community } \\
\text { health/ } \\
\text { community- } \\
\text { based } \\
\text { healthcare }\end{array}$ & Epidemiology & $\begin{array}{l}\text { Impact/ } \\
\text { evaluation }\end{array}$ & Geography & $\begin{array}{l}\text { Health } \\
\text { economics }\end{array}$ & $\begin{array}{l}\text { Health Etc. } \\
\text { policy }\end{array}$ \\
\hline
\end{tabular}

Adherence

Clinical management

Community health/community-based

healthcare

Epidemiology

Evaluation/impact

Geography

Health economics/finance

Health policy and guidelines

Health promotion

Health systems

HIV/AIDS

Human resources/management

Infection prevention and control

Infectious/communicable diseases

Information systems/informatics

Intersectoral collaboration

Intersectoral collaboration, traditional

Malaria

Maternal and child health

Mental health

Non-communicable diseases

Nutrition

Occupational health and safety

Pregnancy-related healthcare

Quality of care

Service delivery

Sexual and reproductive health

Socio-behavioural and cultural factors

Substance use

Tuberculosis

Teenage pregnancy

Traditional medicine 


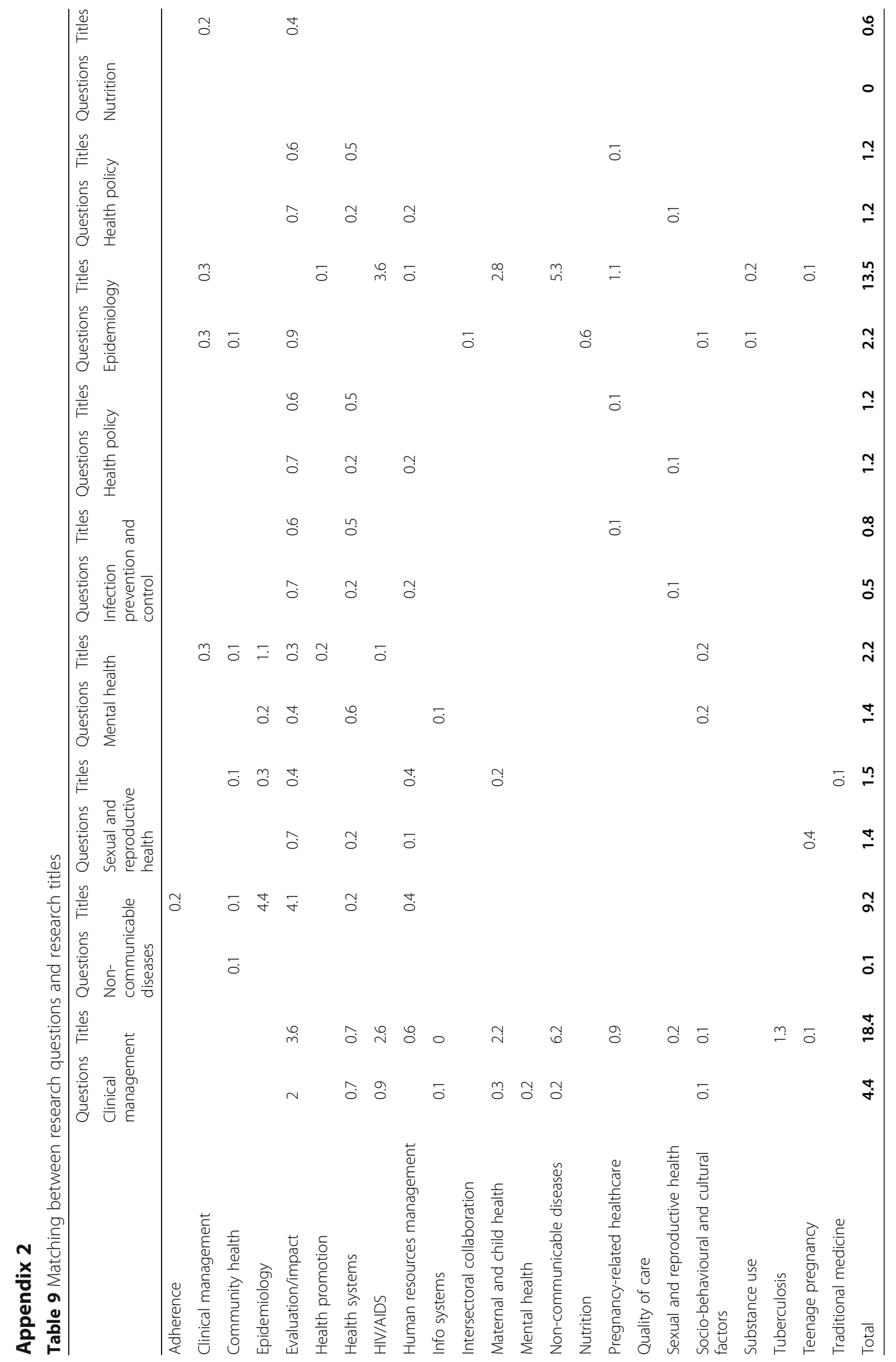




\section{Abbreviations}

HRKMU: Health Research and Knowledge Management Unit; IPC: Infection Prevention and Control; KZN: KwaZulu-Natal; KZN-DoH: KwaZulu-Natal Department of Health; NCDs: non-communicable diseases; NDoH: National Department of Health

\section{Acknowledgements}

The authors wish to thank all the stakeholders that participated on the 2013 research prioritisation process, especially the District Managers, who mobilised and coordinated the stakeholders in their districts to participate in the research prioritisation process. Additionally, they thank Mr. J Govender who supported the entire process from beginning until the end. Finally, they acknowledge the KwaZulu-Natal Department of Health for their approval of the study.

\section{Authors' contributions}

$\mathrm{GK}, \mathrm{EL}, \mathrm{RD}$ and $\mathrm{XX}$ were involved in the writing of the proposal, facilitating the research prioritisation process, data analysis and report writing. SYE and MM facilitated aspects of the research prioritisation process and undertook critical revision of the manuscript.

\section{Funding}

Funding for the research prioritisation process and this research study was obtained from the allocated 2013/2014 annual budget for the Health Research \& Knowledge Management Unit budget. The Health Research \& Knowledge Management Unit is required by the KZN Department of Health to conduct and analyse the research prioritisation process every 5 years.

\section{Availability of data and materials}

The datasets used and/or analysed during the current study are available from the corresponding author on reasonable request.

\section{Ethics Approval}

Approval to conduct this study was obtained from the uMgungundlovu Heath Ethics Review Board (UHERB 170908) and the KZN Provincial Health Research and Ethics Committee (KZ_201648_480) via the National Health Research Database (NHRD).

\section{Consent for publication}

Not applicable.

\section{Competing interests}

Professor Sabiha Essack is chairperson of the Global Respiratory Infection Partnership sponsored by an unrestricted educational grant from Reckitt and Benckiser, UK

\section{Author details}

${ }^{1}$ KwaZulu-Natal Department of Health, Health Research \& Knowledge Management Unit, 330 Langalibalele Street, Pietermaritzburg, South Africa. ${ }^{2}$ School of Nursing and Public Health, University of KwaZulu-Natal, 238 Mazisi Kunene Road, Glenwood, Durban, South Africa. ${ }^{3}$ School of Health Sciences, University of KwaZulu-Natal, 238 Mazisi Kunene Road, Glenwood, Durban, South Africa.

Received: 12 July 2019 Accepted: 7 February 2020

Published online: 18 March 2020

\section{References}

1. Department of Health South Africa. National department of health strategic plan 2010/11-2012/13. Pretoria: Department of Health South Africa; 2010. http://www.nationalplanningcycles.org/sites/default/files/country_docs/ South\%20Africa/south_africa_strategic_health_plan_2010-2013.pdf. Accessed 4 Mar 2019.

2. Provincial Planning Commission. 2035 provincial growth \& development strategy: building a better future together. Pietermaritzburg: Office of the Premier; 2016. http://www.kznonline.gov.za/images/Downloads/ Publications/ppc.pdf. Accessed 4 Mar 2019.

3. Parliament South Africa. National Health Act No 61 of 2003. Pretoria: Government Printers. 2004. Available at: https://www.up.ac.za/media/ shared/12/ZP Files/health-act.zp122778.pdf. Accessed 25 Feb 2020.

4. KwaZulu-Natal Health Act, 2009 (Act No. 01 of 2009), (2009).
5. Bradshaw D, Groenewald P, Laubscher R, Nannan N, Nojilana B, Norman R, et al. Initial burden of disease estimates for South Africa, 2000. S Afr Med J. 2003;93(9):682-8.

6. World Health Organization. Monitoring the building blocks of health systems: a handbook of indicators and their measurement strategies. Geneva: World Health Organization; 2010.

7. Karimkhani C, Trikha R, Aksut B, Jones T, Hall PS, Mitchell ED, Smith AF, Cairns DA, Messenger M, Hutchinson M, et al. The future for diagnostic tests of acute kidney injury in critical care: evidence synthesis, care pathway analysis and research prioritisation. Health Technol Assess. 2018;22(32):1-274.

8. Boyers $L N$, Schlichte $M$, et al. Identifying gaps for research prioritisation: global burden of external causes of injury as reflected in the cochrane database of systematic reviews. Injury. 2016;47(5):1151-7.

9. Okello D, Chongtrakul P. A manual for research priority setting using the ENHR strategy. Geneva: COHRED; 2000.

10. Schneider M. The setting of health research priorities in South Africa. Cape Town: University of Cape Town; 2001.

11. Viergever RF, Olifson S, Ghaffar A, Terry RF. A checklist for health research priority setting: nine common themes of good practice. Health Res Policy Syst. 2010;8:36.

12. Viergever RF, Terry RF, Karam G. Use of data from registered clinical trials to identify gaps in health research and development. Bull World Health Organ. 2013;91:416-25C.

13. Datta R. Decolonizing both researcher and research and its effectiveness in Indigenous research. Res Ethics. 2017;14(2):1-24.

14. Benatar SR. Reflections and recommendations on research ethics in developing countries. Soc Sci Med. 2002;54(7):1131-41.

\section{Publisher's Note}

Springer Nature remains neutral with regard to jurisdictional claims in published maps and institutional affiliations.

\section{Ready to submit your research? Choose BMC and benefit from:}

- fast, convenient online submission

- thorough peer review by experienced researchers in your field

- rapid publication on acceptance

- support for research data, including large and complex data types

- gold Open Access which fosters wider collaboration and increased citations

- maximum visibility for your research: over $100 \mathrm{M}$ website views per year

At $\mathrm{BMC}$, research is always in progress.

Learn more biomedcentral.com/submissions 